\title{
PENILAIAN ALTERNATIF PADA KETERAMPILAN BERBICARA BAHASA INGGRIS DI SEKOLAH MENENGAH KEJURUAN KOTA PONTIANAK
}

\author{
Lilis Listiyawati $^{1)}$, Anggita ${ }^{2)}$, Riska Wahyuni ${ }^{3)}$, \& Heriyanto ${ }^{4)}$ \\ ${ }^{1}$ Jurusan Administrasi Bisnis Politeknik Negeri Pontianak \\ email: lilis_listiyawati@yahoo.com \\ 2 Jurusan Administrasi Bisnis Politeknik Negeri Pontianak \\ email: anggita.anggita8629@yahoo.co.id \\ ${ }^{3}$ Jurusan Administrasi Bisnis Politeknik Negeri Pontianak \\ email: riskawahyuni83@yahoo.com \\ ${ }^{4}$ Jurusan Administrasi Bisnis Politeknik Negeri Pontianak \\ email: heriyanto.radien@gmail.com
}

\begin{abstract}
English speaking skill is an important communication skill and must be mastered by students to be able to interact actively, convey ideas and provide responses in both formal and informal situations. Alternative assessment provides benefits for students and teachers in improving students' speaking skill in English. This research focuses on an alternative assessment of English speaking skill in Vocational High Schools in Pontianak City, especially South Pontianak. The objectives of this research are (1) to determine problems related to the English speaking skill of vocational school students in South Pontianak, (2) to identify and analyze alternative assessments applied in overcoming the problems of English speaking skill of vocational school students in South Pontianak, and 3) to find a solution to the English speaking skill problems of vocational school students in South Pontianak by using alternative assessments. This research was a qualitative research, and data were collected from interviews with English teachers and documents analysis. Data were collected through interviews with English teachers at SMK in south Pontianak and analysis of related documents. The stages of data analysis include data reduction, display data, and conclusion drawing / verification. The results showed that the problems faced by students related to English speaking skill were limited ability of students caused by several factors, namely grammar, pronunciation, vocabulary and self-confidence. The alternative assessments that were applied include performance - assessment, peer - assessment and portfolio. The solutions taken were to involve students in providing assessments to other students and the teacher focuses on conveying information clearly and conveying the moral values that are learned without focusing too much on grammar. The suggestions that the researchers gave were in the form of matriculation for students in the early year of school, knowledge sharing between teachers, determining priority aspects of speaking that were assessed and implementing self-assessment as an additional form of alternative assessment that could motivate and encourage students to gradually improve their speaking skills in English.
\end{abstract}

Keywords: Assessment, Alternative, Speaking, Language, School. 


\section{PENDAHULUAN}

Menilai keterampilan berbicara bahasa Inggris peserta didik (siswa) selalu menjadi sesuatu yang menarik dan menantang karena keterampilan ini berkaitan dengan kinerja lisan sebagai bukti kompetensi menggunakan bahasa. Sebagai bahasa asing, bahasa Inggris masih menjadi salah satu bahasa favorit. Guru menetapkan dan mengembangkan proses belajar mengajar untuk membuat siswa memiliki pengetahuan dan kemampuan untuk berkomunikasi berdasarkan situasi dalam kehidupan sehari-hari. Penilaian yang mengukur kemampuan peserta didik nyata memberikan pengaruh kuat pada guru dan siswa dalam mengembangkan keterampilan ini.

Penutur bahasa Inggris harus memiliki keterampilan berbicara ketika era saat ini memaksa penutur untuk dapat berbicara dengan lancar seperti yang dinyatakan oleh Al-Sibai (2004: 4). Scivener (2005: 146) juga menjelaskan bahwa bahasa adalah sesuatu yang diucapkan yang membuat penutur berbicara harus menggunakannya untuk komunikasi dan tidak hanya sekedar tahu tentang ilmu bahasa saja. Ada beberapa faktor yang berkontribusi pada lemahnya keterampilan berbicara peserta didik dalam Bahasa Inggris, yaitu mereka jarang berlatih menggunakan bahasa yang dipelajari di luar kelas, dan memiliki kepercayaan diri yang rendah dalam menggunakannya. Rababa'h (2005) dalam Al-Hosni (2014: 3) menyoroti faktorfaktor yang mempengaruhi kesulitan berbahasa Inggris dan faktor-faktor tersebut adalah peserta didik, strategi pengajaran, kurikulum dan lingkungan.

Pada dasarnya, penilaian adalah proses berkelanjutan untuk mengukur penguasaan keterampilan bahasa siswa. Dibeberapa Sekolah Menengah Kejuruan (SMK), guru cenderung memilih penilaian berbicara bahasa Inggris secara tradisional mengingat lemahnya ketrampilan berbicara siswa. Para siswa diminta untuk melengkapi atau membuat percakapan sesuai topik yang diberikan, menghafalkannya, menampilkannya di depan kelas dan guru mengamati dan menilai mereka. Penilaian ini masih belum memenuhi tuntutan kurikulum yang menekankan pada pendekatan ilmiah dengan HOTS (Keterampilan Berpikir Tingkat Tinggi). Penilaian alternatif (Alternative Assessment) untuk menilai ketrampilan berbicara dalam Bahasa Inggris siswa (English Speaking Skill) dapat digunakan sebagai alat untuk mengisi kesenjangan antara kurikulum yang diterapkan dan masalah ketrampilan berbicara Bahasa Inggris siswa. Penilaian Alternatif ini memberi kesempatan guru untuk menggunakan penilaian yang lebih kreatif dan adaptif. Berdasarkan fenomena di atas, para peneliti melakukan penelitian tentang Penilaian Alternatif pada Keterampilan Berbicara Bahasa Inggris di Sekolah Menengah Kejuruan di Pontianak (Alternative Assessment on Speaking Skill at Vocational School in Pontianak). Para peneliti membatasi penelitian tentang Penilaian Alternatif pada Keterampilan Berbicara Bahasa Inggris di Sekolah Menengah Kejuruan di Pontianak Selatan (Alternative Assessment on Speaking Skill at Vocational School in South Pontianak). Pemilihan Sekolah Menengah Kejuruan di Pontianak Selatan didasarkan pada wilayah ini terdapat SMKN 1, SMKN 3 dan SMTI dimana ketiga sekolah ini selain menggunakan kurikulum dan mata pelajaran Bahasa Inggris yang sama, merupakan SMKN yang menjadi sekolah yang memiliki kualitas lulusan yang memiliki ketrampilan Bahasa Inggris yang cukup baik dan merupakan sekolah yang sering mengikuti berbagai lomba kejuaraan dengan muatan Bahasa Inggris yang cukup banyak. Selain itu, di wilayah ini terdapat tiga SMK dengan keahlian 
yang berbeda namun memiliki kesamaan mata pelajaran Bahasa Inggris sehingga dapat mencerminkan dan merepresentasikan bagaimana penilaian alternatif yang diterapkan didalam proses belajar mengajar pada sekolah kejuruan secara umum.

\section{METODE PENELITIAN}

Penelitian ini merupakan penelitian kualitatif dan mendiskripsikan penilaian alternatif (Alternative Assessment) yang dilakukan oleh guru bahasa Inggris di SMKN 3, SMKN 5 dan SMK SMTI. Wawancara dilakukan kepada guru-guru yang mengajar di sekolah tersebut dengan berpedoman kepada pedoman wawancara yang berisikan sejumlah pertanyaan untuk menjawab tujuan penelitian ini. Pengambilan data dilakukan selama bulan Juni sampai Agustus Tahun 2020. Wawancara ini dilakukan dengan tatap muka langsung dan melalui Video Call mengingat wawancara dilaksanakan di era pandemi COVID 19 dimana tidak semua informan bersedia ditemui langsung.

Penelitian ini dilakukan di bawah kerangka studi penelitian kualitatif untuk menggambarkan penilaian alternatif yang diterapkan dalam mengukur keterampilan siswa berbicara Bahasa Inggris. Qualitative research admits that the analysis of human activities is by necessity largely subjective and attempts to make the subjective analysis of human behaviour as unbiased as posible (Vockell dan Asher, 1995: 192). Penelitian kualitatif menurut Arifin (2012: 10), adalah suatu proses penelitian yang dilakukan dengan baik dan sesuai dengan kondisi objektif alami di lapangan tanpa manipulasi, serta jenis data yang dikumpulkan terutama data kualitatif.

Informan dalam penelitian ini adalah enam orang guru bahasa Inggris, masing masing dua orang di tiap sekolah. Ada tiga Sekolah Menengah Kejuruan di Pontianak
Selatan yang menjadi pengambilan data penelitian yaitu SMK Negeri 3 Pontianak, SMK Negeri 5 Pontianak, dan SMK SMTI Pontianak. Sekolah-sekolah tersebut dipilih dalam penelitian ini karena mereka mewakili bidang keahlian yang berbeda. Pemilihan informan dilakukan dengan purposive sampling.

Penelitian ini menggunakan sejumlah alat pengumpulan data seperti wawancara mendalam dan studi dokumentasi. Wawancara digunakan sebagai alat utama dalam pengumpulan data dengan menggunakan alat perekam. Pendekatan wawancara semi-terstruktur diadopsi dan pendekatan ini memfasilitasi pemahaman masalah dari perspektif peserta yang diselidiki. Pertanyaan yang diajukan dalam wawancara meliputi, misalnya, masalah dalam berbicara yang dihadapi siswa di kelas, penilaian yang telah diterapkan untuk mengukur keterampilan berbicara, dan hal-hal lain yang berkaitan dengan penilaian alternatif itu sendiri.

Kemudian, dalam melakukan studi dokumentasi, peneliti menganalisa dokumen yang relevan terkait pemberian penilaian alternatif kepada siswa maupun rubrik yang dipergunakan serta penilaian yang dicantumkan dalam RPP masing masing informan.

Dalam penelitian ini, peneliti menggunakan teknik analisis data berdasarkan Miles dan Huberman (1994) yang dikutip Sugiyono (2018: 247-252) yang melibatkan tiga langkah: Data reduction, Data Display, dan Conclusion drawing/verification.

\section{a. Data Reduction}

Langkah pertama dalam menganalisis data kualitatif melibatkan reduksi data. Reduksi data berarti meringkas, memilih hal-hal dasar, berfokus pada hal-hal penting, mencari tema dan pola . Pertama, peneliti mengumpulkan data tentang penilaian alternatif pada SMK melalui wawancara dan dokumentasi. Kemudian, 
peneliti menuliskan data tersebut yang didapat. Data yang tidak relevan atau yang tidak terkait dengan pertanyaan penelitian dibuang.

\section{b. Data Display}

Langkah kedua adalah penyajian data. Proses mengurangi dan menampilkan data didasarkan pada perumusan masalah penelitian. Langkah ini dilakukan dengan menyajikan serangkaian informasi yang terstruktur dan kemungkinan menarik kesimpulan. Dalam penelitian kualitatif, penyajian data bisa dilakukan dalam bentuk uraian singkat, bagan, hubungan antar kategori, flowchart, dan sejenisnya. Peneliti menyajikan data dalam penelitian kualitatif ini adalah dengan teks yang bersifat naratif. Dalam hal ini peneliti menyajikan data dalam bentuk teks, untuk memperjelas hasil penelitian maka dapat dibantu dengan mencantumkan table atau gambar.

\section{c. Conclusion Drawing/Verification}

Kesimpulan dalam penelitian kualitatif mungkin dapat menjawab rumusan masalah yang dirumuskan sejak awal, tetapi mungkin juga tidak, karena seperti telah dikemukakan bahwa masalah dan rumusan masalah dalam penelitian kualitatif masih bersifat sementara dan akan berkembang setelah penelitian berada di lapangan. Kesimpulan dalam penelitian kualitatif adalah merupakan temuan baru yang sebelumnya belum pernah ada. Temuan dapat berupa deskripsi atau gambaran suatu obyek yang sebelumnya masih belum jelas sehingga setelah diteliti menjadi jelas, dapat hubungan sebab akibat atau saling berkaitan Hipotesis atau teori.

Validasi data dalam hal uji kepercayaan terhadap data yang diperoleh dilakukan dengan triangulasi, bahan referensi dan member check. Dalam triangulasi pengecekan dilakukan dengan mengecek data kepada beberapa fihak terkait semisal atasan langsung maupun siswa. Validasi dengan bahan referensi dilakukan dimana peneliti menggunakan alat rekan suara maupun kamera untuk menjamin kredibilitas data. Sedangkan member check adalah diskusi antar pemberi data dan peneliti atas kesuaian data yang diperoleh. Dengan adanya member check peneliti dan pemberi data yang dalam hal ini adalah guru dapat saling mengecek data dan pemahaman yang diambil oleh peneliti sehingga data yang diperoleh oleh peneliti merupakan data yang dimaksud oleh pemberi data.

\section{HASIL DAN PEMBAHASAN}

Dalam pnelitian ini, pengumpulan data dilakukan melalui interviu kepada para informan yang merupakan guru guru yang mengajar bahasa Inggris yang berjumlah 6 orang. Interviu dilakukan dengan Agustus - September 2020 dengan berpedomankan pertanyaan-pertanyaan yang sudah ditentukan dalam pedoman wawancara.

Wawancara dilakukan kepada 6 orang guru sebagai informan bahasa Inggris dari 3 sekolah SMK di kota Pontianak. Karakteristik informan dalam penelitian ini adalah sebagai berikut.

1. Guru Bahasa Inggis SMKN di kota Pontianak.

2. Pegawai Negeri Sipil.

3. Telah mengajar secara formal/ informal minimal 3 tahun.

Untuk mengetahui permasalahan yang berkaitan dengan keterampilan berbicara bahasa Inggris siswa SMK di Pontianak Selatan. Wawancara dilakukan dengan mengajukan beberapa pertanyaan untuk menggali informasi dan data mengenai alternative assessment yang dilakukan oleh para informan dalam menilai ketrampilan berbicara siswa.

Peneliti mengajukan pertanyaan mengenai sudah berapa lama mengajar 
Bahasa Inggris informan 1 menyatakan bahwa sudah mengajar selama 21 tahun, informan 2 selama 10 tahun, informan 3 selama 12 tahun dan informan 4 telah mengajar selama 4 tahun. Informan 5 dan 6 sudah mengajar selama 29 tahun.

Pertanyaan mengenai permasalahan yang berkaitan dengan ketrampilan berbicara Bahasa Inggris siswa informan 1, 3, 4, dan 6 menyatakan permasalahan yang dihadapi siswa berupa grammar, vocabulary dan self confidence. Informan 2 menyatakan permasalahan dalam ketrampilan berbicara siswa adalah grammar, pronunciation dan self confidence. Sedangkan Informan 5 menyatakan bahwa permasalahan siswa dalam ketrampilan speaking adalah vocabulary, pronunciation dan self confidence. Berdasarkan jawaban para informan dapat disimpulkan bahwa permasalahan yang dihadapi siswa terkait ketrampilan berbahasa Inggris adalah tata bahasa (grammar), pelafalan (pronunciation), kosa kata (vocabulary) dan kepercayaan diri siswa (self confidence). Dalam memberikan penilaian kepada siswa, guru melakukan assessment sepanjang semester sehingga permasalahan yang dihadapi siswa akan sangat berpengaruh pada bentuk penilaian alternatif yang digunakan guru. Wilkstorm dalam Azarnoosh (2003) menyatakan bahwa peniliaian perlu dilakukan dalam proses pengajaran, bukan hanya diakhir pengajaran. Dilihat dari permasalahan yang dihadapi siswa, dapat disimpulkan bahwa permasalahan yang dihadapi mengandung dua aspek yakni dari segi pengetahuan kebahasaan dan dari psikologi siswa. Oleh itu penilaian ketrampilan berbicara bahasa Inggris dirasakan cukup sulit. Trent (2009) menyatakan bahwa siswa tidak dapat berbicara bahasa Inggris dengan yakin dikarenakan kepercayaan diri yang kurang. Oleh karena itu penilaian berbicara dalam bahasa Inggris harus menggunakan penilaian yang tepat untuk merefeleksikan pengetahuan siswa sesungguhnya. Pendapat Ginther (2013:1) mendukung hal tersebut dimana penilai menganggap menilai ketrampilan berbicara adalah penilaian yang sulit karena menitikberatkan pada kinerja siswa, dan kemampuan mentransfer ide kepada lawan bicara. Kedua hal tersebut terkait dengan aspek bahasa dan diri siswa itu sendiri yang ikut mempengaruhi pada ketrampilan berbicara dalam bahasa Inggris siswa. Dengan mengetahui permasalahan siswa, guru di SMK dapat memanfaatkan pengetahuan tentang penilain pendidikan utuk memilih dan memanfaatkannya dalam mengatasi persoalan berbicara bahasa Inggris siswa dengan memanfaatkan kekurangan dan kelemahan siswa.

Pernyataan mengenai pentingnya melakukan penilaian semua informan menyatakan penting dilakukan. Adapun mengenai tujuan memberikan penilaian kepada siswa informan 1 menyatakan bahwa untuk mengetahui seberapa jauh tujuan yang dicapai dan dapat ditinjau kembali sesuai dengan yang diharapkan. Informan 2 menyatakan bahwa tujuan penilaian yang dilakukan adalah untuk pengukuran (measurement) kemampuan siswa sekaligus perlakuan (treatment) bagi siswa yang dinilai belum memiliki ketrampilan sesuai yang diharapkan. Informan 3 menyatakan bahwa tujuan penilaian adalah untuk memperoleh umpan balik terhadap proses belajar mengajar yang sudah dilakukan dan mempersiapakan siswa untuk mampu memiliki perolehan nilai yang baik untuk mengikuti tes TOEIC. Sedangkan informan 4 menyatakan bahwa tujuan penilaian adalah untuk menilai kemampuan siswa dalam menyampaikan pesan dan treatment siswa. Tujuan penilaian menurut informan 5 dan 6 adalah untuk mengetahui apakah materi yang diajarkan sudah dikuasai siswa dan 
sebagai guru memperoleh umpan balik terhadap pengajaran yang dilakukan.

Menurut Rahman, Babu \& Ashrafuzzaman (2011) umpan balik yang sistematis merupakan elemen yang penting dalam proses belajar mengajar. Pendapat-pendapat ini sejalan dengan pendapat yang dikemukakan oleh Pompham (2011:8-23) dimana mengemukakan empat alasan klasik mengapa guru perlu memiliki pengetahuan tentang penilaian pendidikan, yaitu (1) mengidentifikasi kekuatan dan kelemahan siswa, (2) melacak keberhasilan siswa, (3) memberikan peringkat, dan (4) menilai keefektifan pengajaran guru. Tiga alasan terkini guru memberikan penilaian yaitu untuk (1) memengaruhi persepsi publik tentang efektivitas pendidikan, membantu mengevaluasi guru, dan (3) menjelaskan tujuan guru dalam mengajar. Dengan memiliki pengetahuan tentang penilaian pendidikan, guru dapat memilih penilaian alternatif yang tepat bagi siswa dan melakukan penilaian karena alasan alasan penting yang dapat meningkatkan kemampuan belajar siswa. Brown (2004) juga berpendapat bahwa penilaian alternatif dapat memberikan kesempatan kepada siswa untuk dapat membuktikan pengetahuan dan ketrampilan mereka dengan menggambarkan kehidupan keseharian siswa.

Untuk mengetahui dan menganalisis penilaian alternatif yang diterapkan dalam mengatasi masalah keterampilan berbicara bahasa Inggris siswa SMK di Pontianak Selatan. Berdasarkan hasil wawancara yang dilakukan kepada enam orang informan yang merupakan guruguru bahasa Inggris di SMK di Pontianak selatan mengenai bentuk bentuk alternative assessment yang dipergunakan adalah sebagai berikut:

\section{Performance Assessment}

Dalam memberikan penilaian ketrampilan berbicara dalam bahasa
Inggris (Speaking), para informan melakukan penilaian alternatif (Alternative assessement) dengan berbagai bentuk.

Informan 1 mengatakan bahwa penilaian dilakukan dengan meminta siswa untuk melakukan unjuk ketrampilan dengan topik seperti greeting dan self introduction. Saat guru menemukan kesalahan siswa dalam mengucapkan kata tertentu, maka guru akan memberikan treatment dimana siswa diminta langsung mengulang kata tersebut dan dibetulkan saat itu juga. Selain itu guru juga memberikan tugas dalam bentuk tugas video dan voice note yang selanjutnya dikoreksi dan dikirim ulang kepada setiap siswa sehingga siswa dapat memperbaiki kemampuan berbicaranya. Penilaian dilakukan dengan overall assessment dengan memberikan nilai A, B, C dan D. Rubrik dianggap rumit dan memakan waktu.

Informan 2 menyatakan bahwa guru memberikan tugas kepada siswa dengan siswa melakukan dialoque, presentasi, debat dan drama. Dalam melakukan penilaian alternatif pada ketrampilan berbicara bahasa Inggris, siswa melakukan tugas secara individu maupun kelompok. Dalam kelompok, guru memilih beberapa orang siswa sebagai tutor sebaya untuk membantu sesama teman melakukan tugas yang diberikan. Penilaian diberikan dengan melakukan overall assessment dengan nilai A, B, C dan D. Rubrik yang disajikan dalam kurikulum dinilai cukup rumit dan terlalu detail.

Informan 3 menyatakan bahwa dalam melakukan penilaian, siswa diminta melakukan unjuk ketrampilan dalam berbagai bentuk seperti presentasi, story telling, dan interview. Dalam presentasi mahasiswa diminta untuk menceritakan berbagai pengalaman dalam melakukan Praktek Kerja Industri (Prakrin). Selanjutnya guru langsung memperbaiki 
kesalahan yang dilakukan siswa setelah siswa menyelesaikan tugasnya. Penilaian tidak menggunakan rubrik tertentu karena dinilai terlalui detail dan membutuhkan waktu yang lama untuk digunakan, sehingga guru hanya menilai dari sudut pelafalan, kosa kata dan struktur kalimat.

Informan 4 menyatakan bahwa dalam memberikan penilaian kepada siswa dimana siswa diminta membaca text tertentu dan melakukan story telling. Selanjutnya guru akan menilai dengan menggunakan rubik yang sudah ditentukan dalam kurikulum K13 untuk menilai dari berbagai aspek. Menurut informan 4, penggunaan rubrik sangat membantu guru dalam menilai berbagai aspek dalam ketrampilan berbicara siswa.

Informan 5 menyatakan bahwa tugas yang dilakukan dengan meminta siswa melakukan dialog didepan kelas berdasarkan percakapan yang diberikan, selanjutnya guru menuntun siswa secara bergantian untuk mengganti situasi yang diberikan untuk membuat dialoq baru. Menurut informan 5 penugasan yang diberikan dinilai sederhana mengingat kemampuan dasar siswa. Penilaian dengan rubrik yang disesuaikan sendiri oleh guru agar lebih sederhana dan memudahkan.

Informan 6 menyatakan bahwa penilaian ketrampilan speaking dilakukan dengan meminta siswa ke depan kelas untuk menceritakan kembali cerita pendek yang diberikan oleh guru, menghapal dialoq dan menampilkannya di depan teman teman di kelas dan membaca text tertentu kemudian siwa lainnya bertanya mengenai isi text tersebut. Guru menilai siswa dengan rentang nilai dengan patokan yang dibuat sendiri yang terdiri dari pronunciation, structure, vocabulary dan intonation. Rentang nilai 60-100.

Penilaian kinerja sebagai salah satu bentuk penilaian alternatif sebagaimana yang dilakukan oleh informan dalam melakukan penilaian ketrampilan berbicara bahasa Inggris siswa tepat dilakukan karena mengaitkan pengetahuan dan pengalaman siswa dengan penilaian yang dihadapinya. Untuk dapat memperoleh hasil penilaian yang baik siswa harus terlibat aktif dalam menyelesaikan tugas yang diberikan dan membutuhkan komitmen untuk melakukan tugas sebaik- baiknya. Ini sejalan dengan pendapat Reeves (2000: 108) dimana penilaian kinerja memiliki lima poin kunci yaitu, berfokus pada pembelajaran yang kompleks, melakukan keterampilan tingkat tinggi dan pemecahan masalah, merangsang berbagai respons aktif, termasuk tugas kompleks yang melibatkan beberapa langkah, waktu yang substansial dan komitmen para siswa. Penilaian alternatif terkait prakrin memberi kesempatan siswa fungsi=funfsi bahasa sebagaimana dinyatakan Kingen dalam ounis (2017).

\section{Self-Assessment}

Penilaian alternatif dengan cara menilai diri sendiri belum dilakukan oleh semua informan. Menurut para informan bentuk penilaian ini membuat pengajar/ guru membutuhkan waktu yang lebih panjang untuk meberikan pemahaman mengenai bentuk penilaian ini dan memastikan setiap siswa dapat membuat butir butir penilaian yang akan diukur dengan benar sesuai dengan target kurikulum dan kemampuan diri setiap siswa. Namun semua informan menilai bentuk penilaian ini sangat efektif untuk memotivasi setiap siswa untuk membuat target pribadi pencapaian yang diharapkan.

Penilaian menilai diri sendiri memberikan manfaat yang besar bagi siswa yang memiliki permasalahan dalam ketrampilan berbicara karena penilaian ditentukan oleh siswa sendiri berdasarkan kemampuan yang dimilikinya. Dengan demikian siswa dapat secara bertahap meningkatkan target penilaian 
mandirinya. Brown dan Hudson (1998) seperti dikutip dalam Brown dan abeywickrama (2010: 145) menjelaskan bahwa Self-Assessment dan PeerAssessment menuntun siswa untuk berpartisipasi, mandiri, dan meningkatkan motivasi terhadap komitmen yang ditetapkan. Penilaiaan diri (selfassessment) tidak digunakan karena siswa harus lebih aktif menentukan penilaian yang akan diukur oleh diri siswa sendiri dan persiapan ini memakan waktu yang cukup lama sehingga penilaian ini belum digunakan.

\section{Peer-Assessment}

Penilaian terhadap unjuk ketrampilan juga dapat dilaukan oleh teman- teman di kelas saat proses belajar mengajar. Mengenai penilaian sejawat (peer assessment), informan 1, 2, 3 dan 4 memberikan jawaban yang sama dimana penilaian dilakukan dengan meminta siwa untuk melakukan tugas yang diberikan di depan kelas secara bergiliran, sementara siwa yang lain mengamati dan memberikan penilaian mengenai kelebihan dan kekurangan yang dilakukan oleh siswa tersebut. Penilaian belum menggunakan skor tententu, namun penilaian hanya berupa kalimat-kalimat seperti sudah benar, sudah baik, dan belum tepat. Aspek yang akan dinilai diserahkan sepenuhnya diserahkan kepada siswa. Selanjutnya hasil penilaian akan didiskusikan secara bersama setelah siswa yang ditunjuk menyelesaikan tugasnya. Informan 5 dan 6 menyatakan bahwa siswa belum mengetahui dan belum dapat memberikan penilaian bentuk ini.

Penilaian alternatif dalam menilai ketrampilan berbicara juga dilakukan oleh sebagian informan. Dalam menilai ketrampilan speaking dengan portofolio, informan 1 menyatakan bahwa belum menggunakan portofolio sedangkan informan 2 menyatakan bahwa portofolio dikelasnya digunakan untuk menilai ketrampilan writing saja. Informan 3 dan 4 menyatakan bahwa alternative assessment dengan portofolio sangat efektif digunakan dalam menilai ketrampilan speaking siswa. Selama melakukan praktek kerja industri (prakrin) siswa diminta untuk membuat laporan berbagai kegiatan yang telah dilakukan. Dalam mata pelajaran bahasa Inggris siwa diminta melakukan presentasi dan materi yang disampaikan disesuaikan dengan meteri dalam portofolio kegiatan prakrin. Bentuk projek dan presentasi yang dilakukan guru mencerminkan penilaian alternatif dilakukan untuk menilai ketrampilan berbicara bahasa Inggris siswa sebagaimana diungkapkan oleh Combe (2007) dalam Azarnoosh (2013:2) mengenai bentuk-bentuk penilaian alternatif seperti self-assessment, portofolio assessment, student-designed test, learner-centered assessment, project dan presentation. Pendapat yang sama juga dikemukakan oleh bahwa presentasi dengan bahasan praktek kerja industri juga merupakan bentuk penilaian alternatif dimana guru melakukan performance assessment sebagaimana dinyatakan oleh Cheng dan Warren (2005) dalam Azarnoosh (2013:2) berbagai alternative assessment dapat digunakan di kelas yang lebih berpusat pada siswa, antara lain performance assessment, portofolio assessment, self dan peer assessment.

Hasil wawancara dari para guru dapat disimpulkan bahwa penilaian alternatif pada ketrampilan berbahasa Inggris siswa SMK menggunakan peer-assessment dan portopolio, Performance assessment sedangkan self-assessment belum digunakan padahal penilaian alternatif ini sangat cocok untuk siswa yang memiliki kemampuan terbatas. Siswa dapat mengeksplorasi kemampuan diri sendiri dalam berbicara berbahasa Inggris. Lebih jauh Moqbel (2015) mengemukakan tiga bentuk penilaian alternatif yang dapat 
dipergunakan untuk mengukur kemampuan berbahasa Inggis siswa yakni Performance assessment, self-assessment, dan peer- assessment yang dapat digunakan sebagai penilaian alternatif. Manakala Combe (2007) dalam Azarnoosh (2013:2) merinci penilaian alternatif seperti self-assessment, portofolio assessment, student-designed test, learner-centered assessment, project dan presentation. Penilaian alternatif akan lebih efektif bila guru memilih penilaian yang tepat yang disesuaikan dengan kondisi siswa dari beberapa bentuk yang dikemukakan oleh para ahli. Selain itu penilaian alternatif harus menjadi sebuah penilaian dalam proses dimana penilaian terjadi sepanjang masa pembelajaran dalam satu semester. Pendapat ini dinyatakan oleh Wilkstorm (2007) dalam Azarnoosh (2013:2). Penilian dalam proses ini baik dilakukan karena kemampuan siswa tidak hanya diukur dalam satu kali pengukuran.

Solusi terhadap masalah keterampilan berbicara bahasa Inggris siswa SMK di Pontianak Selatan dengan menggunakan penilaian alternatif merupakan tujuan ketiga penelitian ini. Berdasarkan hasil wawancara yang dilakukan kepada informan 1 dan 2, penilaian alternatif yang dipilih dan dipraktekkan untuk mengatasi masalah ketrampilan siswa adalah dengan memotivasi siswa untuk melakukan atau mempraktekkan tugas yang diberikan didepan kelas dan meminta teman- teman memberikan penilaian terhadap penampilan temannya dengan memberikan penilaian sederhana dengan mengatakan penampilan baik, sangat baik dan perlu diperbaiki berikut alasannya sehingga siswa lebih percaya diri karena penilaian berasal dari teman sekelas (peer assessment). Selanjutnya pada akhir pelajaran guru akan mengulas beberapa poin penting seperti perbaikan kesalahan pada tata bahasa (grammar) yang masih dilakukan siswa. Informan 2 lebih jauh menyatakan bahwa dengan adanya tutor sebaya dengan melakukan penilaian alternatif lebih memotivasi siswa untuk berbicara walaupun siswa masih memiliki kelemahan pada tata bahasa dan pelafalan. Guru akan memberikan perbaikan atas kesalahan yang dilakukan siswa.

Informan 3 menyatakan bahwa solusi yang dilakukannya dalam mengatasi kesulitan berbicara siswa dengan melakukan peer assessment dan portofolio assessment. Peer assessment menumbuhkan percaya diri yang kuat dan portofolio assessment menjadi lebih mudah dilakukan karena terkait dengan aktifitas yang dilakukan selama siswa mengikuti Praktek Kerja Industri sehingga siswa sudah menguasai content yang berkaitan dengan bidang ilmu (jurusan) yang dipelajari. Komunikasi berjalan dengan baik karena siswa mengetahui dan melaksanakan sendiri aktifitas yang dilakukan selama presentasi. Guru bahasa Inggris berkolaborasi dengan guru pembimbing prakrin untuk kegiatan presentasi ini. Selain itu guru juga memanfaatkan aplikasi quiper dan game untuk meningkatkan kemampuan siswa. Informan 4 menyatakan bahwa solusi yang dilakukan adalah dengan meminta siswa melakukan performance drama dan poster presentation dimana teman sekelas lainnya memberikan penilaian terhadap penampilan siswa yang mengerjakan tugas yang diberikan oleh guru. Guru lebih mengutamakan penyampaian informasi yang jelas dari siswa dan menyatakan moral value yg dipelajari dengan tidak terlalu memperhatikan tata bahasa. Hal ini membuat siswa menjadi memiliki kepercayaan diri untuk melakukan tugas didepan teman temannya karena tidak khawatir membuat kalimat yang salah.

Informan 5 dan 6 menyatakan bahwa penilaian alternatif ketrampilan berbicara masih dinilai hanya oleh guru mengingat kemampuan siswa dan percaya 
diri yang relatif rendah. Siswa hanya memberikan komentar baik dan jelek kepada teman sekelas yang mengerjakan tugas menampilkan dialog yang dihapal sebelumnya dan belum memberikan penilaian. Selain itu guru juga belum memiliki pengetahuan tentang bentuk bentuk penilaian alternatif yang dapat digunakan untuk melakukan penilaian berbicara siswa dalam bahasa Inggris.

Semua informan berpendapat bahwa penilaian alternatif memberikan banyak dampak bagi siswa. Informan 1 menyatakan bahwa penilaian alternatif membuat siswa lebih semangat belajar dan membuat pengukuran yang dilakukan guru lebih baik karena didasarkan pada kesepakatan antar siswa dan guru. Informan 2 menyatakan bahwa penilaian alternatif membuat siswa memiliki karakter yang lebih baik, lebih siap dan bertanggung jawab terhadap penilaian. Khusus penilaian sejawat, informan 2 menyatakan penilian ini memudahkan guru untuk menilai ketrampilan berbicara siswa. Informan 3 menyatakan bahwa dampak penilaian alternatif adalah penilaian menjadi lebih obyektif dan untuk penilaian sejawat, siswa merasa tidak canggung dan menumbuhkan percaya diri. Informan 4 menyatakan bahwa penilaian alternatif membuat siswa dapat mengukur kemampuan sendiri sehingga menjelang ujian akhir semester persiapan yang dilakukan siswa lebih baik. Selain itu siswa menjadi lebih aktif, kreatif dan semangat. Informan 5 menyatakan penilaian alternatif membuat siswa lebih semangat dalam mengikuti penilaian dan informan 6 menyatakan penilaian alternatif memotivasi siswa untuk lebih aktif mengikuti penilaian yang dilaksanakan guru.

\section{SIMPULAN DAN SARAN Kesimpulan}

Berdasarkan hasil penilitian ini dapat disimpulkan bahwa :
1. Permasalahan yang berkaitan dengan keterampilan berbicara bahasa Inggris siswa SMK di Pontianak Selatan adalah terbatasnya kemampuan siswa yang disebabkan oleh beberapa faktor yakni Tata bahasa (grammar), pelafalan (pronunciation), kosa kata (vocabulary) dan kepercayaan diri (self confidence).

2. Penilaian alternatif (Alternative Assessment) diterapkan dengan baik dalam mengatasi masalah keterampilan berbicara bahasa Inggris siswa SMK di Pontianak Selatan dan bentuk penilaian alternatif yang digunakan adalah penilaian kinerja (performance assessment), teman sejawat (peer assessment), dan portofolio yang diwakili oleh 4 orang informan. Namun 2 orang informan menyatakan bahwa baru melakukan penilaian alternatif secara sederhana dikarenakan pengetahuan dasar bahasa Inggris siswa yang relatif rendah. Penilaian diri sendiri (selfassessment) belum dapat dilakukan dikarenakan keterbatasan waktu, persiapan untuk memberikan pemahaman kepada siswa mengenai penilaian ini memakan waktu yang cukup lama.

3. Solusi terhadap masalah keterampilan berbicara bahasa Inggris siswa SMK di Pontianak Selatan dengan menggunakan penilaian alternatif adalah dengan melibatkan siswa dalam memberikan penilaian kepada siswa lainnya dalam melakukan tugas yang diberikan seperti melakukan drama, presentasi hasil praktek kerja, dan poster presentation. Guru lebih memperhatikan bagaimana siswa dapat menyampaikan informasi dengan jelas dan moral value yang dipelajari dengan tidak terlalu menitikberatkan pada tata bahasa. 


\section{Saran}

Setelah melakukan penelitian terkait penggunaan penilaian alternatif, peneliti mengemukakan saran sebagai berikut:

1. Pada saat siswa masuk ditahun pertama di SMK, mereka diberikan program matrikulasi untuk membekali seluruh siswa dengan pengetahuan bahasa Inggris yang sama yang disesuaikan dengan jurusan yang dipilih siswa dan diperkenalkan bentuk - bentuk penilaian alternatif yang akan dipergunakan dalam menilai ketrampilan berbicara bahasa Inggris siswa berikut mannfaat menggunakan penilaian alternatif tersebut. Program ini akan memudahkan guru dalam mengajar dan melakukan penilaian alternatif karena guru dan siswa sudah memiliki persepsi yang sama tentang penilaian alternatif dalam menilai ketrampilan berbicara bahasa Inggris siswa.

2. Guru dapat saling berbagi pengalaman dalam memberikan penilaian alternatif secara internal (knowledge sharing) didalam sekolah maupun eksternal yakni di luar sekolah untuk memilih dan menentukan penilaian alternatif yang cocok sesuai dengan kemampuan siswa sehingga proses penilaian menjadi lebih menyenangkan bagi guru dan juga siswa.

3. Guru dapat menentukan prioritas aspek yang dinilai dalam ketrampilan berbicara siswa sehingga bentuk-bentuk penilaian alternatif yang digunakan akan semakin bervariasi dan menarik bagi guru dan siswa. Self Assessment sebagai sebuah penilaian alternatif dapat digunakan oleh guru untuk

\begin{abstract}
memotivasi siswa dalam mengembangkan diri didasarkan pada pepengetahuan yang siswa miliki dan menimbulkan kepercayaan diri siswa untuk meningkatkan ketrampilan berbicara bahasa inggris secara berkesinambungan.
\end{abstract}

Penelitian lanjutan dapat dilakukan terkait alternative assesment pada language skills lainnya mengingat penelitian ini masih terbatas pada bentukbentuk assessment hanya pada salah satu ketrampilan bahasa yaitu speaking skill.

\section{REFERENSI}

Al - Hosni, Samira.2014. Speaking Difficulties Encountered by Young EFL Learners. IJSLL

Al-Sibai, D.2004. Promoting Oral Fluencyof Second Language Learners: Educational Linguistics.Department of English. King Saud University

Azarnoosh, M. (2013). Peer Assessment in an EFL Context: Attitudes and

Brown, H. D.2004. Langauge Assessment, Principles and Classroom Practices. New York: Pearson Education

Brown, H. D,\& Abiwicakrama P., 2010. Language Assessment: Principle and Classroom Practices. New York: Pearson Education

Fajarsari Linda Ayu.2016. Students' Perception to Alternative Assessment in English Learning at SMA Kristen Satya Wacana Salatiga. English Language Education Program, Faculty of Language and Art, Universitas Kristen Satya Wacana.

Friendship Bias. Language Testing in Asia, a Sprienger Journal, 2.

Ginther, April. 2013.The Encyclopedia of Applied Linguistics. 
Ounis Asma. 2017. The Assesment of Speaking skills at the Tertiary level. International Journal of English Linguistics.7(4):95-112

Popham W. J., 2011. Classroom Assessment (Sixth Edition). Boston: Pearson Education

Rahman, F., Babu, R Ashrafuzzaman. (2011). Assessment and Feedback Practices in the English Language Classroom. Journal of Nepal English Language Teacher' Association (NELTA), Vol 16 No.1, pp. 64-71

Scrivener, J. 1994. Learning Teaching.Oxford: Macmillan Publisher limited.

Sugiyono. 2018. Metode Penelitian Kuantitatif. Bandung: Alfabeta.

Trent, J. (2009). Enhancing Oral Participation Across the Curriculum: some lessons from the EAP classroom. Asian EFL Journal, 11(1), 256-270.

Moqbel, S. S. 2015. Alternative Assessment in EFL classroom: How Effective. Egypt: The Nile TESOL/ AUC Conference

Vockell, Edward L., \& Asher, J. William. 1995. Educational Research. New Jersey:

Prentice Hall, Inc. 